\title{
The European Union's Human Security Discourse: Conceptualization and Justification
}

\author{
Benjamin C. Thompson
}

\begin{abstract}
Human security has been central to "normative power" Europe, hence it is worth asking whether its conceptualization in EU foreign policy and foreign policy discourse is normatively defensible. Important challenges for human security lie in determining how compelling principles can be conceptualized, justified, and practiced for particular missions, and in how these norms relate to the broader legitimacy of missions. After reviewing the human security discourse in the EU and the somewhat sparse normative critiques of it, this article focuses on two principles articulated in the relevant policy discourse: "legitimate political authority" and a "bottom-up" approach. The first requires local consent and support for human security missions, whilst the second requires that missions address the actual insecurities and needs important to beneficiaries. The argument is that this human security approach suffers two problems regarding norm justification and legitimacy. First, there is a tendency to conceptualize human security as an objective norm, whereas the concept only makes sense when understood subjectively through a discursive process between security providers and beneficiaries. These conceptual characteristics are elucidated by considering the debts of human security thinking to the "capabilities approach" to welfare and development. Second legitimizing human security intervention by consent is unhelpful, since what is actually needed is emerging and ongoing discursive political interaction and co-agency with local communities. Since the appropriate procedures for conceptualizing and for legitimizing human missions are procedurally related, adopting an interpretive and discursive approach to human security is recommended for EU security policy.
\end{abstract}

Key Words: European Union, human security, justification, legitimacy, capabilities approach

*Benjamin Thompson(benjamin.c.thompson@hotmail.com) is an assistant professor of political theory at Kyungpook National University. His work is in the history of political thought, particularly Locke and Rousseau. He is also researching methodologies in the social sciences and their significance for debates in normative political theory.

This research was supported by the Kyungpook National University Research Fund (2012) for the grant project entitled "Disaggregating the Capabilities Approach, an analysis of the applicability of the capabilities approach to the just distribution of particular goods, abilities, and opportunities."

The author would like to thank Barbara Kratiuk, Troy Fuhriman, Melinda Szappanyos, and the three anonymous reviewers at The Korean Journal of International Studies for helpful comments on this paper.

The Korean J ournal of International Studies Vol.14, No.1 (April 2016), 161-188.

http://dx.doi.org/10.14731/kjis.2016.4.14.1.161

(c) 2016 The Korean Association of International Studies 
W ith the "Report on the Implementation of the European Security Strategy" (RIESS), the EU brought human security into official security policy (European Council 2008). Over the last 15 years EU High Representatives, the European Commission, the European Council, and the European Parliament have used this principle, whilst NGO actors and policy research groups have engaged with this EU policy discourse (Study Group on Europe's Security Capabilities 2004; Human Security Studies Group 2007; Gottwald 2014; Kotsopoulos 2006; Peyrouse 2011). Mary Martin and Taylor Owen hail this "second generation" of support for a norm that seems waning elsewhere (Martin and Owen 2010). Since the EU is currently replacing its European Security Strategy (ESS) with a new, more comprehensive "Global Strategy" it is worth reconsidering the concept of human security.

The basic EU concept of human security holds that a variety of threats to individuals' lives, freedoms, and opportunities are sources of human insecurity (European Council 2008; Study Group on Europe's Security Capabilities 2004; Human Security Studies Group 2007). What is clear to many commentators is that this human security concept requires further development, both as a general policy and regarding operationalization in specific missions.

Conceptual reform of human security is often recommended from the perspective of social scientific research or technical policy making practice (Paris 2001). Further specification of the human security idea in light of its utility for foreign policy makers is frequently recommended along these technical and scientific lines. Yet the EU's "normative power" in security policy is associated with commitment to and actual practice of human security (Manners 2006), making the normative evaluation of human security especially pressing. Important rationale for this conceptual development is not only to make policy more effective, but to allow human security missions to be justified to recipients (Martin and Owen 2010).

Justifying human security, if it is to be more than a rhetorical maneuver, requires a normative discussion the likes of which have been relatively scarce in EU security policy literature (Bailes 2008, 117). Nevertheless, some cogent objections to human security suggest that it is hypocritical, conceptually self-defeating, serves hegemonic interests, or is impracticable. Such arguments question human security practices, and the general concepts and mission level conceptualizations of the norm. ${ }^{1}$ The problem with human security missions, furthermore, is that

\footnotetext{
${ }^{1}$ This paper uses human security concept to refer to the idea at the general level of EU policy and policy discourse, whilst conceptualization refers to the particular application and interpretation of the concept in particular missions.
} 
they are always disruptive of local political affairs to an extent, and hence they also demand an appropriate account of legitimization (Martin and Owen 2010, 223-224). ${ }^{2}$

The EU discourse may be sensitive to these criteria. Two principles regarding human security, called "legitimate political authority" and the "bottom-up" approach, are important here (Human Security Studies Group 2007). The first requires local consent and support for human security missions, whilst the second requires that the actual basic needs and vulnerabilities of beneficiaries determine the content of human security for a mission (Study Group on Europe's Security Capabilities 2004; Human Security Studies Group 2007). The paper considers the justifiability and legitimacy in practice of the EU's human security approach by critical elaboration and interpretation of these two principles.

Employing the resources of normative political theory, the "capabilities approach" to human welfare and development, 3 and interpretivist theory in the social sciences, the paper finds two problems regarding justification and legitimization in the EU human security approach. First, there is a risk of articulating the basic goals of human security presumptively, which runs counter to the underlying logic of security from objective and subjective, and universal and particular threats to basic human life and wellbeing. Avoiding this risk means rejecting objective and technically precise human security concepts developed in advance. For compelling justifications, human security must be open to the interpretation of meanings and values of and for beneficiaries. Borrowing from John Rawls' (1999; 2005) theory of "overlapping consensus," when interpretation of human security comes through discursive engagement between security providers and beneficiaries, it can be justifiable. Second, "Legitimate political authority" must not be thought equivalent to consent. The paper argues that consent is difficult to express, hard to gauge, and determinations of legitimate consent are significantly troubled, whereas discursive political interaction and coagency with local communities offers deeper legitimization. Because the appropriate procedures for justifying human security concepts and conceptualizations and for legitimizing human security interventions are procedurally related, poli-

\footnotetext{
${ }^{2}$ Justification is used solely in this paper regarding normative accounts in favour of principles or concepts, whereas legitimization is a normative standard applied to human security missions and their practices, and the particular relationship between a security provider and security beneficiaries. Simmons (1999) provides an excellent defence of this distinction.

${ }^{3}$ Variants of human security, including the UN concept and the EU approach, as I show later in the paper, are a conceptual outgrowth of the capabilities approach, and are reliant on its understanding of human capabilities. The object of human security is the security of persons' "basic capabilities" from threats (Gasper 2005).
} 
cies of discursive, overlapping consensus are pivotal for the soundness of the EU's approach.

\section{HUMAN SECURITY IN THE EU}

Before scrutinizing the EU human security approach it is helpful to begin by briefly summarizing the history and recent direction of the EU discourse. The history of human security in general and in the EU is well documented, and it will be tedious to recapitulate this in too much detail. ${ }^{4}$ While the idea of human security can be traced to debates about security and its relation to individual lives dating back to the 1980 os (Marczuk 2008), its emergence as an international normative idea is usually found in the United Nation's Development Programme's Human Development Report 1994. This norm excited a number of states' attention in intervening years including distinctive approaches advanced by Canada and Norway on the one hand and The UN and Japan on the other. But the norm did not really enter into EU policy discourse until the turn of the twenty-first century. A brief synopsis of human security in EU official security policy and in associated policy discourse is useful.

The advent of human security in EU security policy has been traced to 2003's European Security Strategy (ESS), though its inception might be found earlier too. The ESS did not use the term human security, yet it emphasized the importance of non-traditional threats to security and the importance of insecurity specifically as experienced by individuals. The ESS was developed under Javier Solana, then High Representative for Common Foreign and Security Policy. 5 Similarly, the incorporation of human security into later EU security policy came from his behest. His efforts led to the convening of the independent Study Group on European Security Capabilities (SGESC) led by Mary Kaldor, which went on to produce A Human Security Doctrine for Europe or Barcelona Report (Study Group on Europe's Security Capabilities 2004). Among member states, Finland was particularly interested in further developing the policy standing of human

\footnotetext{
${ }^{4}$ For readers interested in a historical treatments see Christou (2014, 366-377), Liotta and Owen (2006), Marczuk (2007, 18-23), Martin and Owen (2010, 216-221), Matlary (2008, 138-140). This list is not exhaustive.

${ }^{5}$ Solana's peer, Benita Ferrero-Waldner, who was Commissioner for External Relations and European Neighborhood Policy until 2009 also supported human security in EU development activities. The nexus of security and development was an important principle of human security at the time, and is crucial for overall normative assessment of the EU's human security approach, but it lies outside the scope of this article.
} 
security. Whilst it held the Presidency of the EU (June-December 2006), Finland had this study group reconvened with the name Human Security Study Group (HSSG) again under Mary Kaldor, which resulted in A European Way of Security or Madrid Report (Human Security Studies Group 2007).

In 2008 human security entered into official policy language in the "Report on the Implementation of the European Security Strategy" (RIESS). The constituent elements of human security also made it into policy in the EU's military "Headline Goal 2010" and "Civilian Headline Goal 2010," which were drafted during Solana's time (European Council 2004; European Council 2007). Civilian and civil-military operability is iterated in "Headline Goal 2010", which is considered instrumental in effecting human security missions (European Council 2004, 4). The Headline Goals do not really lay out any further development of the human security concept, but they are in line with earlier ESS principles in general (European Council 2004; European Council 2007).

Since the Barcelona and Madrid Reports and RIESS, considerable changes occurred to the institutional structure of EU security policy, and its relationship to other aspects of EU foreign policy making and action thanks to the Treaty of Lisbon. The treaty joined up various institutional actors in new ways and gave increased powers to the High Representative to guide and manage EU foreign policy. Important here are whether and in what ways human security continued to matter in EU security policy.

As Christou notes (2014), 2008's RIESS and the efforts of the SGESC and HSSG in the previous years may have been the high water mark of human security in EU security policy. Human security still features in reports and planning after 2008, but it is usually terse. Interest in human security may not have fully taken root in the EU. This reticence toward the concept may be owed to its conceptual ambiguity and breadth, along with inadequate operational consideration (Martin and Owen 2010; Matlary 2008). Certainly, the idea has not been fully able to serve as an overarching strategic narrative framing and guiding the range of EU security and defense policies and actions (Christou 2014; Manners 2007; Peyrouse 2011; Gottwald 2012). As Christou argues, without the driving agency of norm entrepreneurs like Solana, the human security concept is unlikely to regain its presence or to be developed into an overarching strategic narrative (Christou 2014).

Nonetheless, human security continues to matter in EU security policy. Whilst the term appears in the legal and policy language somewhat briefly, the policies contained by that terminology are regularly invoked. The consolidated Treaty on the European Union after the Lisbon Treaty empowers the EU to engage in disarmament, humanitarian tasks, conflict prevention, peace-keeping and peacemaking, anti-terrorism, and other tasks that correspond with human security 
(Treaty on the European Union, Article 43).

Particular EU security missions have also been influenced by human security thinking. EU policy makers in Brussels understood the EU response to the Libyan crisis of 2011 as motivated by human security (Gottwald 2012). Similarly, the European Commission and the High Representative, then Catherine Ashton, in 2013 conceptualized the civil war in Syria primarily as a "human security" crises and recommended a response accordingly (European Commission 2013). In less well-known efforts, the EU has also used human security language to conceptualize security challenges in the Sahel region of Africa (European Union External Action Service 2011).

Currently, EU High Representative Federica Mogherini is guiding a major review of European external action, which is expected to result in a new "Global Strategy" for the EU. Human security, or policy ideas conceptually related to it, feature in this ongoing process, and they may be present in its outcome.

The European Parliament has commissioned a substantive recommendation for this process, entitled Towards a new European Security Strategy? (TANSS). The report emphasizes human security in regard to threats posed by cyber vulnerabilities and nuclear energy infrastructure in some states, climate change, and maritime security (Anthony, Grand, and Lewis 2015, 26, 29-30). TANSS finds that organized crime, drug and human trafficking, human rights abuse, crime in politics, small arms, political extremism, and discrimination against minority groups and LGBT persons all contribute to insecurities in the Balkans for states, groups, and individuals (Anthony, Grand, and Lewis 2015, 39).

The High Commissioner has also invited and published online a number of expert opinions in advisement for the "Global Strategy." This process is ongoing, and so far has maintained the presence of the human security idea regarding nuclear weapons, terrorism, organized crime, and environmental degradation (Nafaa 2016).

Hence, human security is poised for the next generation of EU foreign policy doctrine. Even if the EU's Global Strategy eschews the term human security, the normative ideas it encapsulated will remain pressing. The ongoing crises of governance, civil war, terrorism, and migration around, into, and through Europe are potent evidence that the concerns of human security will remain material whatever the fate of the terminology. ${ }^{6}$

From this overview of human security in EU policy and policy discourse it is evident that the work on human security in EU policy discourse, along with its pres-

\footnotetext{
${ }^{6}$ The connection between these phenomenon and human security, and insecurity, is discussed by Kaldor in recent work on "new wars" (2012).
} 
ence in policy discourse peaked in 2008. Subsequent uses of human security have been terser and have not developed the concept beyond the Barcelona and Madrid Reports. It remains to be seen how this discourse deals with the normative basis of human security activities, particular justification of principles and legitimization of missions. The next section turns to these concerns.

\section{JUSTIFICATION AND LEGITMACY IN EU HUMAN SECURITY DISCOURSE}

I want to unpack the EU human security concept and its normative elements. Before doing so, it is worth emphasizing the differences of the EU approach with older concepts of human security. The UN approach, seconded by Japan, tended to explore a broad network of security threats to individuals. By contrast, Canada, Norway and a few other Human Security advocates emphasized a narrower range of dangers to individuals' physical safety. The former, more maximal set is often thought so broad and complex that it made establishing priorities and operationalizing human security policy all but impossible (Paris 2001). The minimalist Canadian approach does not suffer these difficulties, but it excludes real threats to dignified, worthwhile, or simply tolerable human life. The EU approach shares the UN commitment to inclusion of any threat to dignified and tolerable life. But unlike the EU approach, it allows an operational focus through a threshold test (Owen 2004; Martin and Owen 2010). Of course, the understanding and identification of threats and the determination of a relevant threshold are conceptual challenges as are the theory and research by which these understandings and determinations are reached.

Within EU human security discourse a more specific set of principles has been developed to elaborate how such a flexible human security ideal could be addressed to actual insecurity crises. These principles are found in the aforementioned Barcelona and Madrid reports, which recommend a more or less common policy framework. I will treat them together but will follow the structure of the more recent Madrid Report. The principles are "the Primacy of Human Rights," "Legitimate Political Authority," "A Bottom-up Approach," "Effective Multilateralism," "An Integrated Regional Approach," and "Clear and Transparent Strategic Direction” (Human Security Studies Group 2007, 4-5, 910,15-19). Though not named in exactly the same way, these ideas also appear in the "Report on the Implementation of the European Security Strategy" (RIESS). The rest of this section considers these principles and the prospective importance of the bottom up approach and legitimate political authority for justifying and 
legitimizing human security in EU policy.

"The primacy of human rights" is a respect for economic, social, civil, and political human rights in human security missions (Human Security Studies Group 2007, 9). This means that the protection and promotion of individuals and their human rights cannot be traded off against some other class of interest, value, or objective, such as state security or the safety of participating soldiers (Study Group on Europe's Security Capabilities 2004, 10-11; Human Security Studies Group 2007, 9).

"Legitimate political authority" describes both the goal of a mission and its initial legitimation. The goal is to create a legitimate political authority (Study Group on Europe's Security Capabilities 2004, 15; Human Security Studies Group 2007, 9). Accordingly, military force may be needed to stabilize an insecure area "so that a space can be created for a political process" (Study Group on Europe's Security Capabilities 2004, 16). In practice this has meant supporting states, but international, national and local governance solutions are also conceivable. Consent seems to be the principle of legitimizing human security missions that involve "intervention," and both locals and the international community should approve (Human Security Studies Group 2007, 9). Because the Barcelona Report states that the use of military force "can only succeed on the basis of local consent and support," legitimate political authority also describes the condition of authorization by which a mission could be successfully legitimized (Study Group on Europe's Security Capabilities 2004, 16). It is unclear what kind of chronology is envisioned for this consent and support. Creating space for a political process may be compatible with gaining consent after a mission commences. Subsequent sections of this article return to this. The Madrid report takes several EU missions to task for not living up to the legitimate political authority principle, while also asserting that local "co-decision" making can be a way of establishing it (Human Security Studies Group 2007, 16). This is contended without clear reference to whether this point pertains to the goals of missions or to a condition of legitimizing interventions.

The "bottom-up approach" establishes the reasons for intervention, and the policies to be adopted on the "the most basic needs identified by the people who are affected by violence and insecurity" (Study Group on Europe's Security Capabilities 2004, 13). This requires a process of on-going and "intensive consultation" both before and after a decision to intervene (Study Group on Europe's Security Capabilities 2004, 13). The basic recommendation is for discursive practices of information sharing and consultation, and eventually implementation (Study Group on Europe's Security Capabilities 2004, 14). In 2004 it was unclear if this interaction was to be for advisement, or if it extends, potentially to partic- 
ipation in planning and policy making. But by Madrid, the study group had shifted their language, arguing that "more could be done in terms of freeing up individuals and civil society to be the architects and engineers of their own recovery, and in allowing them to arbitrate the results of external intervention" (Human Security Studies Group 2007, 17). These points are important, since they will eventually say something about the kind of conceptualization of human security appropriate for cooperation and decisions of this kind. They also show that in practice, there could be convergence between legitimate political authority and the bottom-up approach, since the discursive space necessary for political legitimacy also creates the political space needed for local planning and arbitration of mission outcomes. How this is to be orchestrated conceptually and normatively is unspecified.

The EU should not arbitrarily and unilaterally conduct human security interventions that involve coercive force; this is the principle of "effective multilateralism." It is not to be confused simply with having a coalition of states involved with a mission (Study Group on Europe's Security Capabilities 2004, 12). Three additional requirements are pivotal. First, working with international institutions and with their procedures is required (Study Group on Europe's Security Capabilities 2004, 12). Second, common ways of working including common rules and norms must be established among partners in a mission (Study Group on Europe's Security Capabilities 2004, 12). Third, real coordination rather than duplication of effort among partners and institutions is required (Study Group on Europe's Security Capabilities 2004, 12). Effective multilateralism is connected to the international consent needed to legitimize human security interventions. It also, allegedly, separates this kind of intervention from neo-imperialism. This is important, since below we see that allegations of neo-imperialism are significant normative claims against human security. Yet the Barcelona Report's assertion is unconvincing since international norms and international agreement are neither necessary nor sufficient to refute neo-imperialism. ${ }^{7}$ However, the absence of neo-imperialism might be shown to beneficiaries if legitimate political authority and a bottom up approach include convincing norms of justification and legitimization. This is the subject of the analysis to come.

The "integrated regional approach," is the recognition that conflicts do not follow borders, and so solutions will have to take in the region holistically, both concerning the dynamics of conflict and regarding who partners with the EU in delivering human security (Study Group on Europe's Security Capabilities 2004, 14).

\footnotetext{
${ }^{7}$ That imperialism was often facilitated by international agreement and international norms under the Concert of Europe and the League of Nations evinces the weakness of this claim.
} 
"Clear and Transparent Strategic Direction" is intervention with clear legal authorization, mandates, and a coherent overall strategy. In missions, there should be close links between policy makers and people in the field, with the former having ultimate control over operations. Specifically, EU external engagements should be led by civilians (Human Security Studies Group 2007, 10).

Several of the concrete principles recommended in the Barcelona and Madrid Reports also appear in the official RIESS. The primacy of human rights as a human security principle for all of the European Security and Defence Policy (ESDP) and all of the challenges it faces is made imperative by RIESS (European Council 2008, 10). So too the importance of effective multilateralism features in this policy update (European Council 2008, 11). RIESS holds that Legitimacy cannot be equated with participation in or representation in international institutions, which gestures to the principle of legitimate political authority (European Council 2008, 12). Concurrent with its emphasis on multilateralism, regional solutions are also prioritized (European Council 2008). So too are partnerships with local stakeholders, which suggests concrete policy alignment with the bottom-up approach and legitimate political authority principles (European Council 2008, 8).

Though these six principles are relevant to the justification and legitimacy of actual human security missions, legitimate political authority and the bottom-up approach seem the most pivotal yet the most troublesome conceptually. They are important because neither the specification of the goals of human security missions nor the satisfaction of political legitimacy can rely on international consensus alone, according to the internal logic of the EU approach. The EU human security ideal, thus, demands some kind of local engagement. Although the Barcelona and Madrid Reports assert the normative significance of effective multilateralism, it is hard to see how this contributes in itself to either justifications or legitimacy vis-a-vis beneficiaries of a human security mission. This shifts the normative burden to legitimate political authority and the bottom-up approach. These principles remain loosely defined and the values they are meant to respect hard to pin down. Thus, legitimate political authority and the bottom-up approach require further elaboration to consider their adequacy for justifying and legitimizing EU human security policy and interventions. The purpose of the next section is to review normative assessments of the EU's human security approach and establish the groundwork for subsequent assessment. 


\section{CRITIQUES OF THE EU APPROACH}

The idea of human security has been the subject of several different kinds of normative objection. These claims are closely related to the concept and conceptualizations of human security and to the justification of these. The concept of human security has been questioned both because of the context of its origination and because of the adequacy of the concept itself. The purpose of this section is to review these critiques and consider their applicability to the principles of justification and legitimization already included in the EU human security policy discourse.

A basic normative worry about the concept of human security is that it is too vague, broad, and(or) complex (Kotsopoulos 2006, 10-11; Matlary 2008, 141; Paris 2001). Des Gasper admits that human security is really a discourse or a network of concepts, values, goals, and instrumental ideas (Gasper 2006, 222). This leads to a number of worries. For Roland Paris, this aspect of human security is conceptually problematical since it lacks the precision and parsimony useful for testing causal relationships between variables (Paris 2001, 93; 2004, 371). This makes it hard to employ for both policy makers and social scientists, harkening back to Giovanni Sartori's criticism of conceptual overstretch in political science (Sartori 1970). This objection itself is not particularly compelling because its dictum of concept formation relies on problematical presumptions. These problems have been drawn out by work of interpretivists in the social sciences. Paris commits to a kind of conceptual essentialism - a problem by which conceptual criteria are separated from actual social meaning and phenomenon (Bevir and Kedar 2008). Likewise, such conceptualizations are insensitive to trade-offs with a host of other valid conceptual considerations (Gerring 1999). These trade-offs include normative criteria, since narrowing human security may be arbitrary. If conceptual complexity is a problem, this gains normative traction because of consequentialist reasons. Because of the vagueness and complexity of human security perhaps it cannot: a) be operationalized effectively (Paris 2001); b) garner widespread institutional support (Martin and Owen 2010); c) be placed into a convincing narrative (Christou 2014; Manners 2007; Peyrouse 2011; Gottwald 2012); and d) prioritize the various threats which it might address (Paris 2001). A), b), and c) are largely empirical matters, and success or failure of human security in these domains may be contingent on a number of other phenomenon, rather than consequences of a particular human security conceptualization. D) is more significant because it alleges a necessary outcome of the internal incoherence of human security.

Taylor Owen, Mary Martin, and Gaspers have discussed how the prioritization 
problem can be resolved by devising a human security approach already attending to priorities (Gasper 2006; Owen 2004; Martin and Owen 2010). EU human security policy is a close fit to the threshold test for human security concern Owen proposes (Owen 2004). Rather than resolving the complexity of human security by arbitrarily focusing on a narrower range of threats, the EU directs its attention to crises of human security. Human insecurity obtains when thresholds are passed in terms of the number of persons effected and the intensity of the threats they suffer (Martin and Owen 2010, 221). Both the EU discourse and Owen are somewhat vague about establishing actual thresholds. This may seem vexing for the effective prioritization of human security concerns, since it sounds perhaps like a banal stipulation to take serious threats seriously. But it may be better to see Owen's proposal as a rule for how to undertake prioritization amongst a given set of human security threats with a given and limited set of foreign policy resources. The threshold approach thus avoids the arbitrary fixity of more precise conceptualizations and leaves room for the vicissitudes of the real world. Empirical and social conditions, rather than conceptual parsimony, can guide prioritization, and this will be of significance in the discussion to come.

Another pronounced worry is that the EU currently has focused only on relatively low intensity missions, including the normal practice of peacebuilding, dialogue building, and local government retraining and retooling. If a threshold approach to human security is part of the EU policy ideal, why has the EU sometimes been irresponsive to intense or pervasive threats, such as its longstanding inaction regarding genocide in Darfur (Bailes 2008, 120)? The apprehension is that EU human security is effectively window dressing. Were the EU to pursue human security outcomes more systematically and effectively, and were it to attend to the greatest crises more consistently, then this hypocrisy would cease. Notice, however, that this may actually be a critique of EU decisions, their institutional complications, and member state interests, which have hampered needed human security missions. Thus, the ethics of EU external action and its "normative power" is an important topic (Manners 2006), but it is not that of this paper.

Returning to worries about the vagueness and breadth of human security, a final reason for "drilling down" the concept has been offered. This is not only for consequentialist reasons of policy prioritization and implementation, but also for reasons of basic justification (Martin and Owen 2010, 223; Peyrouse 2011, 4). That such justification is currently wanting because of an inadequate concept of human security is more than plausible.

Critical security studies invokes a more radical set of normative concerns, which question whether the ideal of human security is justifiable at all. Scholars 
working within the critical security studies traditions have problematized the idea of human security (Newman 2010). Critical assessment recognizes the political presuppositions of the language, concepts, and practice of human security. While having exercised human security work through governmental and nongovernmental multilateralism, the EU approach presumes that the EU along with member and partner states will be primary security providers. In this context of state centric activity, human security could be seen as a "problem solving" idea (Newman 2010, 89). Furthermore, the great majority of EU external security missions have aimed to rebuild state governing capacities. If this is so, then human security is thoroughly entrenched in both reproducing the Westphalian structure of international relations and the practices of this state system. From the critical point of view, this leaves the moral goals of the human security ideal vulnerable. Protecting the vital core of human wellbeing from pervasive or critical threats sounds laudable, but many of these threats are integrally related to systemic global economic, social, and power inequalities on which the current state system relies (Newman 2010). Hence, EU human security activities may patch over these systemic inequalities while leaving many of the world's population vulnerable to them. More confrontationally, human security may actually serve as little more than rhetorical cover for self-interested western interventions or neo-colonialism. It may be, if this assessment holds, a hegemonic concept.

Critical security worries about human security and more conventional conceptual objections share the view that human security is currently hard to justify in practice. The critical security approach, further, is skeptical that such justifications can be developed at all, even provided further conceptualization of human security policy. Nonetheless, Newman believes that a kind of "critical human security" may be possible, and he suggests that commentators and policy makers bring to bear the resources of contemporary political theory to achieve this (Newman 2010, 91-94). If EU human security is to be appropriately justified perhaps this is already plausible with legitimate political authority and the bottomup approach. It is worth turning to the justification of human security directly.

\section{JUSTIFYING HUMAN SECURITY PRINCIPLES}

Justifying EU human security policy concepts concerns the type of reason that will be made available for these principles. Justifying mission level conceptualizations of human security may seem to be applying the rationale of an already fixed concept of human security. Part of the argument of this section is that such an understanding of justification is inadequate. The key challenge for justifying 
EU human security lies both in determining the manner by which particular and local insecurities, which cannot be determined presciently, may be discovered and addressed. Justification, if it is to obtain, is thus intimately connected to the "bottom-up approach" introduced above, but requires a discursive, procedural dimension that elicits local participation for interpreting relevant security and insecurity values.

One way of justifying EU human security norms might be by offering reasons for already established policy ideals. This follows Janne Matlary's argument that the normative basis of human security policy is to be detangled from operational concerns (Matlary 2006, 116). If she is right, then the normative justification of EU human security missions would be prior to these operational concerns. Such a view takes the human security idea to be normatively compelling in its own terms and needing no revision or reconsideration in particular operational settings. Recommendations to "drill down" human security to better promote EU foreign, defence, and security policies are compatible with the same preconception of the norm before actual missions. Here, justification becomes almost a sales pitch, the rhetoric of which seems discernible in relevant policy recommendations (Kotsopoulos 2006, 13-14).

The problem is that no matter how the characteristics of a human security concept are postulated prior to the justification of mission level conceptualizations, this runs the risk of missing the local meanings and values important to beneficiaries (Bevir and Kedar 2008). The exclusion of local values from the development of human security conceptualizations may be why accusations of hegemony or neo-imperialism have been cogent.

Even if it is recognized that some additional content must be provided to human security conceptualizations respecting the particular needs of specific groups in actual missions, this adjustment still leaves the concept of human security presupposed. If this is the justification expected of the "bottom-up" approach, then it is inadequate because the elements of human security delineated prior to missions would still be vulnerable to critical security studies objections.

There is an alternative approach which allows conceptualization and justification of human security to coincide. This alternative is based on "overlapping consensus" and "public reason." Both ideas are articulated by John Rawls (1999; 2005), but their relevance to this aspect of EU foreign policy can be drawn from their role in current political theory on the international human rights regime. I have in mind Jack Donnelly's particular discussion of the "relative universality" of human rights. Donnelly extends the notion of overlapping consensus to show why a set of universal human rights norms are justifiable and justified (Donnelly 2007, 290). Human rights are justifiable because they can be and have been 
understood from a variety of different moral perspectives, not simply western liberal ones. This is overlapping consensus. Charles Beitz and Joshua Cohen have argued similarly (Beitz 2001; Cohen 2004). They are justified because this conceptual consensus has been reached largely through voluntary political processes (Donnelly 2007, 291-292) often involving commitment to public reasoning. They are justified also because human rights norms invite a plurality of local interpretation and enforcement practices (Donnelly 2007, 298-301), which is relative universality. These features of justification defuse the claim that human rights are a hegemonic or neo-imperialist concept. Peter Sutch has made a similar, though broader, point about the justification and legitimation of norms in the international community through, and not before, political and normative practices (Sutch 2001, 195-199). By capturing overlapping consensus and procedures of public justification, human security and human security missions in particular would become more credible.

Human security must be thought of as an open concept, inviting subjective and local perspectives for particular conceptualizations, to be compatible with the forms of justification outlined above. Is the EU idea of human security inclined toward such openness?

The concept of security itself is important in answering this. To describe elements of advantage and well-being as secure is not to say that they are enjoyed presently. A moment's reprise is not the same as security. To identify human security or insecurity, rather, is a claim about the resiliency of its elements over time. This holds notwithstanding what particular elements are included and notwithstanding whether some threshold must be reached before human security is violated. Security connotes not only an objective status, but also the reasonable expectations of those who enjoy it. The worry and terror that whatever advantages one presently holds can be lost without warning is material to insecurity. Enduring subjective feelings of misgiving are an objective disadvantage (Wolff and De-Shalit 2007). Assurance is an element of human security, and this can only be understood in subjective terms.

The discourse of human security is also inclined to a fundamentally open and revisable sense of the objects of security. The inheritance of human security from what is called the "capabilities approach" to development and welfare is important here. Early advocates of human security were keen to connect it to development. They saw human security perhaps as an initial step toward development, making the latter possible, and understood security and development in terms of "capabilities" or "human functionings" (Gasper 2005). Amongst these proponents were Amartya Sen, the progenitor of the capabilities approach, in Human Security Now (Commission on Human Security 2003), and Sabina Alkire, who 
was lead researcher at the UN's Commission on Human Security in the same period and a prominent contributor to the capabilities approach (Gasper 2005, 225; Alkire 2002). Whereas the development discourse involved expanding and improving human capabilities available for individuals, human security can be aptly understood as prioritizing and protecting the most needful of these capabilities (Gasper 2005). As Alkire puts it, human security preserves the "vital core" of human lives, i.e. "a minimal or basic or fundamental set of functions related to survival, livelihood and dignity" (Alkire 2003, 24).

After being first promoted by Sen and later Martha Nussbaum, the capabilities approach has become paradigmatic in developmental economics. It is worth elaborating here, for understanding the capabilities basis of human security bears upon the justifiability of the concept and its conceptualizations. For Sen, capabilities can be described as the set of worthwhile or valuable potential functionings (states of being and doing) of which a person may avail. Functionings, or beings and doings, include having gainful employment, a medical insurance policy, being free from criminal threats, living in a city with a multiplex cinema, hiking, reading and being able to read, and so on. Capabilities involve the abilities, opportunities, and meaningful choices that individuals can make amongst different possible functionings. The capabilities approach holds that individual wellbeing can be assessed by valuing and measuring the range of capabilities individuals possessor perhaps the range of functionings to which they have access.

This kind of an understanding seems linked to the EU understanding of human security as well. One of the key elements of human security can be protection of the vital core of human lives. We have seen how both protection from physical dangers and from poverty, extreme inequality, absence of good governance, and extreme under development are contained within the EUs human security approach. This human security idea can be understood as securing "basic-capabilities." For Sen "basic capabilities" are those necessary to satisfy a minimum of functionings basic for human life, which resembles Alkire's vital core. For Nussbaum, basic capabilities are those particular capabilities which are themselves vital. The EU discourse reflects a commitment to securing access to basic capabilities, not simply physical safety, from the worst threats. Importantly, the Barcelona and Madrid Reports indicate that needs identified by people in want of human security should be included in such a list. But the EU's human security approach is not clear on how exactly the list of basic needs, or capabilities ought to be populated. It is also unclear how locally identified needs would be interpreted. These issues deserve attention because they are crucial for questions of justification of both the capabilities approach and human security.

In the capabilities literature, there is similar consternation over whether the 
most crucial human capabilities can be delineated objectively. Do all people in all societies require the same capabilities? Or are there some basic objective capabilities and others subjectively or regionally variable? The debate can be framed as a difference between Amartya Sen's and Martha Nussbaum's interpretations of the capabilities approach. For Nussbaum, a list of crucial and apparently universal capabilities can be devised, though she does not insist it is irrevocable (Nussbaum 1988; 2011). This list includes: life; bodily health; bodily integrity; sense, imagination and thought; emotions; affiliation; other species; play; and control over one's environment (Nussbaum 1988; 2011). What concerns the analysis here is not so much what Nussbaum includes in the list, but her confidence in the apparent universality of these capabilities.

For Sen, capabilities must be open-ended and emphatically so. This is not only because of uncertainty over what capabilities might actually count in different places and times, but because the advancement and securement of capabilities must be via deliberative engagement with the peoples and societies meant to be served. A theory "cannot 'freeze' a list of capabilities for all societies for all time" since capabilities must be evoked through citizens' understandings, "social reality," and "the reach of democracy" (Sen 2004, 78).

This incompleteness has another dimension as well. This occurs because different capabilities, even the most basic ones, may require relative prioritization that a list cannot itself show. Sen uses the example of basic access to food and to shelter. Depending on the context, the relative priority of these physical necessities changes; homeless refugees amid a freezing winter require shelter especially, but famine conditions in North Korea leave nourishment wanting amongst the largely sheltered population (Sen 2004, 78).

Nonetheless, the capabilities approach can be applied to a variety of different purposes. The particular exercise, practice, or policy to which it is attached qualifies whether and how particular capabilities may be justifiably determined. If such a purpose is simply to generate an index or statistical measure, perhaps the informational restriction of an expert's list is appropriate (Sen 2004, 79). There is no necessary incompatibility between Nussbaum's enthusiasm for listing capabilities and Sen's aversion either, since Nussbaum's contribution is to public debate and reasoning about capabilities, not policy. But the human security application of the capabilities approach is importantly different. Actual human security missions are interventions, disruptions, contributions to governance, modifications to law and order, and so on. In this sense, the conceptualization of human security must withstand scrutiny that voices in public debates or statistical indices need not. In this, success is more likely if human security comes to include deeper and more accurate information about what intended beneficiaries 
actually understand and value.

Such justifiability is not yet tantamount to justification. Here Sen's language of citizens' valuation and democratic choice makes a crucial additional point. A set of capabilities is justifiable when composed though a process of public inquiry, consultation, and politics. This rules out any definitive, operationalized listing of particular threats in advance of a human security mission. In a human security intervention, adopting public procedures of conceptualization is crucial to justification.

This is a pivotal lesson. For human capabilities to be realized, they have to be available and meaningful to and recognized by particular individuals, in particular contexts. These capabilities have to have significance to the people who hold them. This is relevant to the basic idea of human security, at least in its EU formulation, since the basic threats to security concern more than just the physical safety of individuals, but basic capabilities, especially those which allow other skills, abilities, opportunities, and functionings to be gained. In so far as human security concerns subjectively understood basic capabilities and their relative prioritization in a given social context, it is incoherent for its content to be stipulated pre-emptively. The norms of human security are therefore provisional, revisable, and open for localization.

These points about the notion of security and about the open-ended, contextually dependent, and subjective content of human security can be satisfied with overlapping consensus and public reasoning. The language of the Madrid Report indicates some compatibility with this procedural approach to conceptualizing and justifying human security. Yet for the EU to actually engage in this flexible and discursive approach, it will have to become equipped for security research appropriate to participation in public reasoning and overlapping consensus. Human security cannot be understood objectively, and it cannot be understood apart from interactions with local beneficiaries and the interpretation of their meanings, beliefs, and practices. The EU should equip itself with research expertise in the realm of "interpretivist" social sciences, which details and defends the interpretation of social meanings, interests, and shared goods, and which possesses an extensive toolkit for conducting such research rigorously. ${ }^{8}$ These include the discipline of ethnographic research for instance, which can help the EU initiate the kind of consultations called for in the Madrid and Barcelona. This is only a first step. But the better the EU is prepared to make sense of local understandings of basic capabilities and to reconceptualize human security where

\footnotetext{
${ }^{8}$ For readers seeking introduction to the range and depth of interpretive political science, see further Bevir and Rhodes (2016).
} 
appropriate, the better it can effect actual justification with local stakeholders. Hence, calls to create a more analytically precise notion of human security put the cart before the horse and must be resisted. The operationalization that human security might require can only be justified through a discursive process between the EU and its intended beneficiaries. The bottom-up approach of EU human security policy is best interpreted as having this significance.

\section{HUMAN SECURITY MISSIONS: LEGITIMACY AND CONSENT}

The EU, as a foreign policy actor, stands in a relationship with its abroad that provides no initial legitimacy regarding interventions of any kind. Governments may intervene in coercive and non-coercive ways with their own citizens, and the EU may impose restrictions and directives on its member states. The EU and its member states may promote human security internally because they already possess legitimacy at home. ${ }^{9}$ But unlike in Europe, the EU has no such legitimacy abroad. Normatively, it must gain legitimacy in order to interfere within other states, just as a state must have legitimacy to govern at home. An important part of the concept of human security, therefore, must be its comportment with appropriate norms of legitimacy and legitimization regarding interventions.

This section argues that legitimization cannot be inferred from the justification of human security because of the coercive and(or) disruptive nature of intervention. Turning to consent based understandings of legitimization, these are rejected because consent comes before the robust application of the bottom-up approach discussed above, which seems an unappealing trade-off. Nevertheless, legitimate political authority and the bottom-up approach to justification converge in an important way. If the bottom-up approach to conceptualizing and justifying human security is accepted, this requires a discursive political space which could contribute to legitimization through EU and local co-agency.

Some voices on human security in Europe indicate that compliance with international norms and defensible normative bases for human security are sufficient to obtain this legitimacy (Matlary 2006, 113-119; Matlary 2008, 134). The legitimacy of an operation cannot be obtained simply because they are well intentioned, follow international law, and have the support of "effective multilateral-

\footnotetext{
${ }^{9}$ The actual legitimacy of the EU to legislate and make policy within Europe is in fact deeply contested. Despite the persistence of a democratic deficit in the EU and questions this raises for EU legitimacy, it is the case that the EU possesses at least legal legitimacy to govern within the competencies conferred to it by its constitutive treaties.
} 
ism" or a UN mandate, or any other justification because legitimization concerns particular political relationships rather than the value of principles (Simmons 1999). The sad lessons of Afghanistan are illustrative of the difference (Martin and Owen 2010, 223).

A brief consideration of Responsibility to Protect (RtoP) helps illustrate the difference between justification and legitimization. This norm grounds coercive interference in a state or region on a now multilateral norm of international law regarding massive human rights violations. But the RtoP norm does not purport to legitimize intervention only because of positive and customary international law. The reason RtoP is seen as legitimate is also because it values human life and dignity in a justifiable way. It aims to protect some of the gravest human rights interests of individuals and groups. Restoring the interests of persons not to be victims of serious violations of international humanitarian law, let us assume, is justified. Similarly, the basic idea of the EU's human security approach is that each human life is worth protecting from threat. In the case of RtoP, it seems there is some reasonably objective benefit for those protected by interventions of this kind. This is because RtoP is focused on the kind of human rights violations which constitute grave threats to individuals' physical safety. The benefits of the broader range of human security concerns may be trickier to treat objectively as discussed above. It is still unclear if protecting these interests is itself adequate for legitimization.

One way of thinking about this inadequacy lies in seeing that the protection of some fundamental interests may be both an outcome yet also a motive for interventions. A mission that purportedly serves these norms may actually be motivated disingenuously even if it delivers positive results. This point is registered by worries that the EU's current human security missions have actually been products of ulterior motives, or have failed to respond to some of the worst human security crises (Matlary 2008, 142; Bailes 2008). This, however, seems a criticism of EU agency rather than the human security concept.

Consider further that the majority of the EU's security policy missions have been to restore state governing capacities. This means either working to prop up existing but malfunctioning governments while also evoking commitment to human security, or working with many groups and other international actors to develop new governing institutions. A good case and point can be found in the Libyan crisis. After it became clear that the Gaddafi regime no longer warranted legitimacy abroad or at home, the EU backed the Libya Contact Group's decision in July 2011 to recognize the Transitional National Council (TNC) as the legitimate governing authority (Gottwald 2012, 19). ${ }^{10}$ Another example can be found in the EU's work in Mali where it has combined a military and civilian mission to 
assist national government in providing security and territorial control, in part by training soldiers and improving the local chain of command (Main aspects 2015, 216).

The legitimacy of EU missions in cases like these intertwines with the legitimacy of the local government and its institutions. Because human security is almost always about preserving or restoring government and governance, the legitimacy of human security missions like these cannot be established simply on the basis of general normative goals or interests, though these also stand in need of justification as we saw above. This condition is probably the case in almost all human security missions which have any coercive, disruptive, legislative, or administrative aspects for the simple reasons that these issues always require authorization of particular actors and institutions with particular competencies in regard to particular groups (Simmons 1999). Otherwise, the idea of political legitimacy could not be distinguished from vigilantism.

Thus, the principle of "legitimate political authority" pertains especially to legitimizing human security missions. Currently, the EU discourse understands legitimate political authority in terms of requiring local consent for human security missions. The discourse is not clear about the meaning of this consent. In human security missions it is possible, chronologically, for consent to be acquired before a mission begins. This is quite unlike established and stable political societies, where consent has been widely seen as logically insufficient for political legitimacy because there are no opportunities for it to be exercised in an ongoing polity. For a human security mission though, consent can be given in response to an offer of assistance by the EU. Consent could also be interpreted as tacit consent. Tacit consent is assumed on the basis of non-objection or some acceptance of benefits, in this case those provided by a mission. I will suppose that tacit consent is particularly unappealing since it would make legitimacy trivial and arbitrary to satisfy.

There are several difficulties which confront legitimization through actual consent. A) it is hard to identify and justify an interpretation of who should offer consent. B) consent may be obscured in extreme cases of human insecurity. C) in any human security mission the interactive process that would ground the bottom-up approach above could only come after the offering of consent and the mission begun, thus leaving legitimate political authority and the bottom-up approach at odds.

${ }^{10}$ The Libya Contact Group, established March 2011, was an international group assembled to coordinate intervention in Libya. It included 21 countries, the Arab League, the Cooperation Council for the Arab Gulf States, the EU, NATO, and the Organization of the Islamic Conference. 
In the Barcelona and Madrid Reports there is uncertainty as to who or what could give consent. Should it be individuals, or various groups or populations that must exercise such a claim? Only human insecurity faced by some considerable number of individuals could justify foreign policy missions under the EU threshold understanding. But such a number may simply be a collection of individuals, or it may constitute a group, or several groups. The Yazidi in Iraq have come to extreme harm and endangerment as a group, and their insecurity can only be understood because of this. How is it to be clear when such a collection of individuals, of groups, or both support and consent to a human security mission?

Individuals and groups could be seen as rights holders or potential claimants under the human security approach advocated by the EU. There is no logical problem in a complex value like human security mattering both to individuals and to groups. However, if human security gives both individuals and groups claims to assistance, it may mean that they could make conflicting claims. So too might individuals might make conflicting claims. Such conflict is hardly unexpected, but it does make valid consent for human security missions hard to identify if and where it obtains. It is clearly inadequate for anything like a majority, super majority, or consensus to be a condition for consent or support, since often minority groups are subject to extreme insecurity when majorities are not, as the Kosovars experienced in Serbia in the late 1990s. But it is equally disruptive and perhaps arbitrary for the EU to consider it legitimate to intervene only if some particular groups request it.

Beyond these questions it also remains unclear how groups of people ought to voice consent. Is it by preponderance of individual claims amongst the group? Through which channels may it be issued? Is some other outcry actionable? If it is a social group that is insecure, can consent be offered through some form of authoritative representation - as a legal corporation would do? What if the group has no such organization, or is itself in turmoil, or group institutions and practices threaten its own members? Can support be issued through the interpretation of consultative meetings with EU staff, or with local actors brought on-board by the EU to participate in such consultations? Such practices are discussed in the Barcelona and Madrid Reports, but not in a way that would tell how they could constitute legitimate consent. These are not simply rhetorical questions, for they point out the very difficult complexities that the EU would face in determining consent in almost any environment racked with human insecurity.

It is important also to recognize that consent is always communication. In places where freedoms of speech are generally well respected, or where freedoms of speech have proven difficult to suppress, it is plausible to imagine widespread outcry at situations of pervasive or acute human insecurity. The Twitter presence 
of the Iranian Green Movement comes to mind. But it is worth recognizing that for many people, being in a state of human insecurity may mean communications of any kind, particular toward international actors, will be fraught with danger. Similarly, access to communicative technologies or media might be hard to come by. To require consent in advance is, potentially, to deny human security assistance to individuals and groups in situations like these.

This runs counter to the basic principle of human security that each and every human ought to be secure in the basic freedoms, rights, and needs that comprise the "vital core" of their lives. I have argued that determining this vital core will actually depend on an open and discursive conceptualization, but this is not to argue against common intersubjective or even objective elements to the concept. In situations where communication is dangerous or untenable, it is imaginable that such objective elements of human security would be threatened. Moreover, these situations would also threaten any discursive processes both local and international by which human security could be conceptualized locally. Requiring actual consent prior to intervening in cases of human insecurity like this seems dangerously incompatible with the basic norm of human security.

This point leads to another: consent prior to the commencement of a human security intervention means that the discursive process by which the bottom-up approach works is also left until too late. Of course it is likely that the human security goals, and ways and means, identified for a mission must be revisited, and this may be done with discursive consultation after the fact, correcting initial inadequacies. Preliminary consultations before such a mission may also be possible, but in situations of extreme human insecurity these will be hard and dangerous for locals to participate in. These imply two realizations. Firstly, it is only after the reconceptualization is undertaken that local beneficiaries of the mission may have human security aims they find meaningful, justifiable, and appropriate for consent and support. Consent would actually be found after the fact, and would require ongoing earlier processes of justification and legitimization.

Secondly, if consent predates a truly bottom-up approach to the human security mission, this may condone path dependencies despite future reflections on lessons learned. The EU's decision to recognize the TNC in Libya or its efforts to restore governance capacities in Mali are precisely ones that introduce likely path dependencies. More forceful military intervention than the EU has undertaken to date, but which may be appropriate in severe crises, is even more worrisome in this regard. Such decisions and their ramifications are precisely the kind which demand both careful justification and legitimization. Legitimization would require revisiting the terms of the relationship between security provider and beneficiary as it develops over time. This is an incredibly thorny problem, and it 
is not clear that path dependencies can in fact be fully revisited. Much depends on issues of structure and agency which lie outside the scope of this paper. Nonetheless, the norm of consent offers little impetus for confronting such pathdependent difficulties.

Consent, then is inappropriate as a prerequisite for human security missions. If a local warlord, or political party has engaged in a long term civil war, conscripts child soldiers, enslaves mining labor, and the local government engages in equally harmful policies, it is hardly unthinkable that human security could be aptly restored with peace keeping intervention. The success of the UK's Operation Palliser, starting in May 2000, in drawing civil war in Sierra Leone to a close exemplifies this. Consent is too strict because the vulnerabilities described above make it difficult for consent to be issued, because it is hard to know who would consent in a case like that in Sierra Leone, and because it circumvents the longer and more discursive processes by which human security is justifiably conceptualized and operationalized - the bottom-up approach. What is needed is a mode of legitimization for EU missions, which brings these complexities aboard. This should be an ongoing interactive process of developing co-agency.

\section{CONCLUSION}

This paper has considered questions about how human security ought to be conceptualized in EU missions. Although calls to clarify the concept of human security are often allied with a desire for greater analytical clarity or precision, this goal has been resisted here. Although a clarified concept might expedite EU planning, it would run afoul of the conceptual openness needed to justify human security in actual missions. It would also pre-empt the kind of discursive and political interaction by which such justification could occur. All this would also make the EU human security vulnerable to objections by critical securities scholars that it simply reiterates the priorities of the existing state system.

The paper has rejected legitimizing human security missions by consent, showing that this principle is inadequate in serious ways. Danger and interference with the discursive conceptualization of human security are prominent among these inadequacies. While justification is not tantamount to legitimization, the procedures of justification seem allied with ones that might also legitimize human security missions over time.

The current EU human security discourse is open to the kind of robust justification described so far, depending on how it its principles are interpreted. The bottom-up approach is pivotal to this, but it must not be understood simply as 
providing human security goals and means presumed relevant to local communities. These desiderata must be determined discursively. It is only through interactive procedures and eventually politics that a human security mission could be legitimized. This is a claim that follows arguments made above by accepting the idea that practices of justification and of legitimization are intertwined. By participation in practices of justification outlined above, local beneficiaries have actually participated in the policy making and implementation of human security for themselves. This participation is policy making co-agency, and a more robust form of legitimization than consent.

The article has not proposed any particular arrangements for undertaking the discursive pursuit of overlapping consensus it recommends. This is because fixing such procedural recommendations in advance seems unjustified. Just as the norms of human security must be open to revision through discursive agreements between the EU and particular peoples in particular places, so too the procedural instruments by which justified conceptualizations and legitimization come into place may differ from place to place. Nonetheless, the EU may prepare itself with an interpretive understanding of both the kind of goals that might constitute a local understanding of human security, and the kinds of practices by which these goals might be discussed and evoked. The Barcelona and Madrid reports perhaps conflate such an interpretive toolkit with the more discursive interactions the bottom-up approach should entail, but it is significant that EU policy has tentatively alluded to these themes. It remains to be seen what 2016's Global Strategy will mean for human security in the EU. Given that the underlying concerns of human security will matter for the foreseeable future, the normative framework outlined here is relevant for the EU's normative power and policy.

\section{REFERENCES}

Alkire, Sabina. 2002. Valuing Freedoms: Sen's Capability Approach and Poverty Reduction. Oxford: Oxford University Press.

Anthony, Ian, Grand, Camille, and Lewis, Patricia. 2015. "Toward a New European Security Strategy? Assessing the Impact of Changes in the Global Security Environment?" European Parliament, DirectorateGeneral for External Policies, Policy Department. Accessed at http://www.europarl.europa.eu/thinktank/en/document.html?reference=EXPO_STU(2015)534989 (January 31, 2016).

Bailes, Alyson J.K. 2008. "The EU and a 'Better World': What Role for the European Security and Defence Policy?” International Affairs 84(1), 115- 
130.

Beitz, Charles R. 2001. "Human Rights as a Common Concern.” American Political Science Review 95(2), 269-282.

Bevir, Mark and Kedar Asaf. 2008. "Concept Formation in Political Science: An Anti-Naturalist Critique of Qualitative Methodology.” Perspectives on Politics 6(3), 503-516.

Bevir, Mark and Rhodes, R. A. W. eds. 2016. Routledge Handbook of Interpretive Political Science. London; Routledge.

Christou, George. 2014. “The European Union's Human Security Discourse: Where Are We Now?” European Security 23(3), 364-381.

Cohen, Joshua. 2004. "Minimalism about Human Rights: The Most We Can Hope for?” The Journal of Political Philosophy 12(2), 190-213.

Commission on Human Security. 2003. Human Security Now. Accessed at http://www.un.org/humansecurity/sites/www.un.org.humansecurity/fi les/chs_final_report_-_english.pdf (February 13, 2016).

Donnelly, Jack. 2007. “The Relative Universality of Human Rights.” Human Rights Quarterly 29(2), 281-306.

European Commission. 2013. "Join Communication to the European Parliament, the Council, the European Economic and Social Committee and the Committee of the Regions, Towards a Comprehensive EU Approach to the Syrian Crisis.” Accessed at http://eeas.europa.eu/statements/docs/ 2013/130624_1_comm_native_join_2013_22_communication_from_ commission_to_inst_en_v10_p1_7332751.pdf (February 13, 2016).

European Council. 2004. "Headline Goal 2010" Accessed at http://www.consilium.europa.eu/uedocs/cmsUpload/2010\%20Headline\%20Goal.pdf (January 30, 2016).

. 2007. "Civilian Headline Goal 2010." Accessed at https://www.consilium.europa.eu/uedocs/cmsUpload/Civilian_Headline_Goal_2010.pdf (January 30, 2016).

. 2008. "Providing Security in a Changing World." Report on the Implementation of the European Security Strategy. Accessed at europa.eu/globalstrategy/en/report-implementation-european-security-strategy-providing-security-changing-world (January 25, 2016).

European Security Strategy. 2003. A Secure Europe in a Better World. Accessed at http://www.consilium.europa.eu/uedocs/cmsUpload/78367.pdf (January 30, 2016).

European Union External Action Service. 2011. "Strategy for Security and Development in the Sahel.” Accessed at http://eeas.europa.eu/africa/ docs/sahel_strategy_en.pdf (February 13, 2016). 
Gasper, Des. 2005. "Securing Humanity: Situating 'Human Security' as Concept and Discourse." Journal of Human Development and Capabilities 6(2), 221-245.

Gerring, John. 1999. "What Makes a Concept Good? A Criterial Framework for Understanding Concept Formation in the Social Sciences." Polity 31(3), 357-393.

Gottwald, Marlene. 2012. "Humanizing Security? The EU's Responsibility to Protect in the Libyan Crisis." Finnish Institute of International Affairs Working Paper 75. Accessed at http://www.fiia.fi/en/publication/261/ humanizing_security/ (February 1, 2016).

Human Security Studies Group. 2007. A European Way of Security. The Madrid Report on the Human Security Studies Group comprising a proposal and Background Report. Accessed at http://eprints.lse.ac.uk/40207/ (January 30, 2016).

Kaldor, Mary. 2012. New and Old Wars: Organised Violence in a Global Era 3 rd ed. Cambridge: Polity Press, 2012.

Kotsopoulos, John. 2006. “A Human security agenda for the EU?” European Policy Centre Issue Paper 48.

Manners, Ian. 2006. "European Union 'Normative Power' and the Security Challenge." European Security 15(4), 405-421.

Marczuk, Karina Paulina. 2007. "Origin, Development and Perspectives for the Human Security Concept in the European Union." Romanian Journal of European Affairs 7(2), 14-32.

Martin, Mary and Owen, Taylor. 2010. "The Second Generation of Human Security: Lessons from the UN and EU Experience." International Affairs 86(1), 211-224.

Matlary, Janne Haaland. 2006. "When Soft Power Turns Hard: Is an EU Strategic Culture Possible?” Security Dialogue 37(1), 105-121. . 2008. "Much Ado about Little: The EU and Human Security." International Affairs 84(1), 131-143.

Nafaa, Hassan. 2016. "EU Global Strategy Expert Opinion 7." EU Institute for Security Studies. Accessed at https://europa.eu/globalstrategy/en/euglobal-strategy-expert-opinion-no7-26-january-2016 (February 12, 2016).

Newman, Edward. 2010. "Critical human security studies." Review of International Studies 36(1), 77-94.

Nussbaum, Martha. 1988. "Nature, Function, and Capability: Aristotle on Political Distribution." In Julia Annas and Robert H. Grimm eds., Oxford Studies in Ancient Philosophy, Supplementary Volume, Oxford: Oxford 
University Press, 145-154.

. 2011. Creating Capabilities: The Human Development Approach. Cambridge, MA: Harvard University Press.

Owen, Taylor. 2004. "Human Security - Conflict, Critique and Consensus:

Colloquium Remarks and a Proposal for a Threshold-based Definition." Security Dialogue 35(3), 373-387.

Paris, Roland. 2001. "Human Security; Paradigm Shift or Hot Air?" International Security 26(2), 87-102. . 2004. "Still an Inscrutable Concept." Security Dialogue 35(3), 370-372

Peyrouse, Sebastien. 2011. "Human Security in Central Asia: Can the EU help out?” EUCAM Policy Brief 21.

Rawls, John. 1999. A Theory of Justice (Revised Edition). Cambridge, MA: Harvard University Press. . 2005. Political Liberalism (Expanded Edition). New York: Columbia University Press.

Sartori, Giovanni. 1970. "Conceptual Misinformation in Comparative Politics." American Political Science Review 64(4), 1033-1053.

Sen, Amartya. 2004. "Capabilities, Lists, and Public Reason: Continuing the Conversation." Feminist Economics 10(3), 77-80.

Simmons, A. John. 1999. "Justification and Legitimacy." Ethics 109(4), 739-771.

Study Group on Europe's Security Capabilities. 2004. "A Human Security Doctrine for Europe.” Barcelona Report of the Study Group on Europe's Security Capabilities. Accessed at http://www.lse.ac.uk/ internationalDevelopment/research/CSHS/humanSecurity/barcelona Report.pdf (January 30, 2016)

Sutch, Peter. 2001. Ethics, Justice and International Relations; Constructing an International Community. London: Routledge.

United Nations Development Programme. 1994. Human Development Report 1994. Oxford: Oxford University Press. 